\title{
Effect of supplemental vitamin $E$ on the performance of growing-finishing pigs fed stored versus freshly harvested barley and on the storage stability and eating quality of frozen pork
}

\author{
Kaija Suomi \\ Agricultural Research Centre of Finland, Animal Production Research, Pigs, Tervamäentie 179, \\ FIN-05840 Hyvinkää, Finland, e-mail: kaija.suomi@mtt.fi \\ Kirsi Partanen \\ Agricultural Research Centre of Finland, Animal Production Research, Animal Nutrition, \\ FIN-31600 Jokioinen, Finland \\ Timo Alaviuhkola, Hilkka Siljander-Rasi \\ Agricultural Research Centre of Finland, Animal Production Research, Pigs, Tervamäentie 179, \\ FIN-05840 Hyvinkää, Finland \\ Satu Sankari \\ University of Helsinki, Faculty of Veterinary Medicine, Department of Clinical Veterinary Medicine, PO Box 57, \\ FIN-00014 University of Helsinki, Finland
}

\begin{abstract}
A $2 \times 4$ factorial experiment was conducted with 80 growing-finishing pigs to evaluate effects of barley storage (stored barley harvested the previous year or freshly harvested barley) and supplemental vitamin E (0, 40, 80 or $160 \mathrm{mg} / \mathrm{kg}$ as all-rac- $\alpha$-tocopheryl acetate) on pig performance and the storage stability and eating quality of frozen pork. Pigs were fed isoenergetic barley-soybean meal diets and vitamin $\mathrm{E}$ was rationed on the top of feed, a 2-d dose at a time. Stored and freshly harvested barley contained 33.5 and $31.2 \mathrm{mg} / \mathrm{kg}$ of vitamin $\mathrm{E}$ in the beginning and 33.0 and $38.7 \mathrm{mg} / \mathrm{kg}$ at the end of the study, respectively. Supplemental vitamin $\mathrm{E}$ had a quadratic effect on pig growth $(\mathrm{P}<$ 0.05), the greatest weight gains being observed with $40 \mathrm{mg} / \mathrm{kg}$ of supplemental vitamin $\mathrm{E}$ in both barley diets. Vitamin E supplementation increased linearly serum $(\mathrm{P}<0.001)$ and quadratically back fat $\alpha$-tocopherol $(\mathrm{P}<0.01)$. Plasma gluthathione peroxidase activity increased as pigs grew older $(\mathrm{P}$ $<0.001)$, and at slaughter it decreased linearly with supplemental vitamin E $(\mathrm{P}<0.05)$. Dietary vitamin E supplementation did not affect the content of thiobarbituric acid reactive substances (TBARS) or the organoleptic quality of pork stored frozen $\left(-18^{\circ} \mathrm{C}\right)$ for 16 weeks. The TBARS content of pork increased with time (0 to $8 \mathrm{~d})$ thawed meat was displayed under fluorescent light at $8^{\circ} \mathrm{C}$ $(\mathrm{P}<0.001)$ which was detected as a poorer taste. In conclusion, supplemental dietary vitamin $\mathrm{E}$ above $40 \mathrm{mg} / \mathrm{kg}$ feed does not improve pig performance nor the storage stability or eating quality of frozen pork when freshly harvested or stored barley from good harvest conditions is fed to growingfinishing pigs.
\end{abstract}

Key words: cereals, meat quality, oxidation, $\alpha$-tocopherol

(C) Agricultural and Food Science in Finland

Manuscript received December 1998 
Suomi, K. et al. Effect of vitamin E on pigs and frozen pork

\section{Introduction}

Traditionally, it is believed that freshly harvested cereals have a low vitamin E content or that vitamin $\mathrm{E}$ is poorly available immediately after harvesting and drying. Dried, stored barley is however a good natural source of vitamin $\mathrm{E}$. Vitamin E develops in barley during the milk ripeness stage, i.e. several weeks before harvesting, and the content is similar to that of fully matured barley (Kivimäe and Carpena 1973, Pohjanheimo et al. 1975). The vitamin E content of cereal grains is influenced by several factors, e.g. harvesting time, weather, drying, handling and storage time (Kivimäe and Carpena 1973). According to Hakkarainen et al. (1983b) the moisture content of stored grain is one of the critical factors affecting the vitamin E content of grain.

Eight isomers of vitamin $\mathrm{E}$ occur in nature, and $\alpha$-tocopherol has the greatest vitamin $\mathrm{E}$ activity (Ullrey 1981). Generally, it is also the isomer which is analysed in feeds as well as being used for dietary supplementation (Ullrey 1981). According to Työppönen et al. (1988) $\alpha$-tocopherol isomer accounts for over $90 \%$ of vitamin $\mathrm{E}$ in pig tissue. The vitamin $\mathrm{E}$ in freshly harvested barley is absorbed at a similar efficiency as that in stored barley or that as all-rac- $\alpha$-tocopheryl acetate. Supplemental vitamin E resulted in similar tissue vitamin $\mathrm{E}$ concentrations in pigs, irrespective of the storage time of barley, and $40 \mathrm{mg} / \mathrm{kg}$ was enough to maintain serum vitamin E concentration at $0.3 \mathrm{mg} \alpha$-tocopherol/g lipid (Työppönen et al. 1988). When barley from poor harvest year is fed to pigs, greater vitamin E supplementation may become necessary, because the natural vitamin $\mathrm{E}$ content is lower than that in a crop harvested in good conditions (Hakkarainen et al. 1983a). In addition, both stress and dietary fat supplementation increase the vitamin E requirement of pigs (Ullrey 1981).

Meat quality declines during the long term freezer storage of pork primarily due to fat oxidation (Pearson et al. 1977). This is because carbonyl compounds that are formed in fat oxida- tion have strong off-flavours (Pearson et al. 1977). Dietary vitamin E supplementation has been shown to prevent the oxidation of unsaturated fatty acids and the formation of oxidation products in pork (Monahan et al. 1992b). The content of oxidation products in meat is measured as thiobarbituric acid reactive substances (TBARS) (Astrup 1973). Abundant vitamin E supplementation (100 to $200 \mathrm{mg} / \mathrm{kg}$ ) as all-rac$\alpha$-tocopheryl acetate has decreased TBARS content and thus oxidation risk in pork during freezestorage (Monahan et al. 1992a).

The aim of this study was to investigate whether growing-finishing pigs require additional vitamin E supplementation, i.e. above $40 \mathrm{mg} /$ $\mathrm{kg}$ feed, when they are fed freshly harvested or stored barley and to evaluate the effect of dietary vitamin E supplementation on the storage stability and eating quality of frozen pork.

\section{Material and methods}

\section{Animals, diets and measurements}

Eighty pigs (16 Yorkshire, 25 Landrace and 39 crossbred) of initial body weight $26.6 \pm 0.65 \mathrm{~kg}$ were used in a $2 \times 4$ factorial growth experiment ( 5 gilts and 5 barrows per treatment) in two randomised blocks, with each block consisting of 40 pigs (the distribution of races was $7+13+$ 20 or $9+12+19$ per block, respectively). The factors were barley storage (stored or freshly harvested) and dietary vitamin E supplementation $(0,40,80$ or $160 \mathrm{mg} / \mathrm{kg}$ in the form of allrac- $\alpha$-tocopheryl acetate). Prior to this study, pigs received barley-oats-fish meal-soybean meal diet with $25 \mathrm{mg} / \mathrm{kg}$ of supplemental vitamin E. Experimental diets consisted of stored or freshly harvested barley and soybean meal as the protein source (Table 1). Both barleys were of variety 'Pohto'. Stored barley was produced in 1993 and freshly harvested barley in 1994, both on the same field under good harvesting conditions. Pigs were fed twice a day according to a 
Vol. 8 (1999): 9-18.

restricted age-based feeding scale (1.2 to 2.8 feed units/d) for 15 weeks. Vitamin $\mathrm{E}$ was given to pigs every second day on the top of feed, a 2-d dose at a time.

\section{Chemical analyses and organoleptic grading}

Feed ingredients were analysed for proximate composition according to standard procedures (AOAC 1990). Barleys were analysed for selenium according to Kumpulainen and Saarela (1992). Vitamin $\mathrm{E}$ isomers were determined in barleys at the beginning and the end of the study by high performance liquid chromatography (Piironen et al. 1984). The total vitamin E content, i.e. as $\alpha$-tocopherol equivalents, was calculated from different isomers according to McLaughin and Welhrauch (1979).

Blood samples were taken from vena jugularis of three randomly selected gilts and two barrows per treatment before the experiment started, $30 \mathrm{~d}$ later and at slaughter (104 d). Plasma and serum was separated by centrifugation (3000 rpm for 10 minutes) and serum was analysed for $\alpha$-tocopherol (Biesalski et al. 1986) and plasma for gluthathione peroxidase (GSH-Px) activity (Günzler et al. 1974). Samples were also taken from the back fat of the same animals at slaughter and analysed for $\alpha$-tocopherol content by high performance liquid chromatography using fluorescence detection (Biesalski et al. 1986). Six 1.5-cm thick samples were cut from the longissimus muscle of two gilts and three barrows per vitamin E level (same animals as before). Meat samples were vacuum packed and stored frozen $\left(-18^{\circ} \mathrm{C}\right)$ for 16 weeks, after which they were thawed at $4^{\circ} \mathrm{C}$ for $18 \mathrm{~h}$, removed from the vacuum package, and kept under fluorescent light (Philips DLD $58 \mathrm{~W} / 86_{5}$ ) at $8^{\circ} \mathrm{C}$ for 0,3 or $8 \mathrm{~d}$. Meat samples were fried and graded for organoleptic quality (taste, tenderness and juiciness) by a five member panel using a seven point scale ( 7 was the best and 1 the poorest score ) as described by Siljander-Rasi et al. (1996) and analysed for TBARS using the procedure of
Table 1. Formulation and chemical composition of experimental diets.

\begin{tabular}{lcc}
\hline & SB-diet & FHB-diet \\
\hline Ingredient composition, g/kg & & \\
Stored barley (SB) & 779 & - \\
Freshly harvested barley (FHB) & - & 779 \\
Soybean meal & 185 & 185 \\
Mineral-vitamin mix. ${ }^{1}$ & 35 & 35 \\
L-lysine-HCl & 1 & 1 \\
Calculated chemical composition & & \\
Dry matter, g/kg & 868 & 873 \\
Net energy, FU/kg ${ }^{2}$ & 0.91 & 0.91 \\
Crude protein, g/FU & 169 & 180 \\
Crude fat, g/FU & 21.4 & 23.2 \\
Lysine, g/FU & 9.1 & 9.6 \\
Ileal digestible lysine, g/FU & 7.5 & 7.8 \\
Calcium, g/FU & 9.7 & 9.7 \\
Phosphorus, g/FU & 7.8 & 7.8 \\
Selenium, mg/FU & 0.3 & 0.3 \\
Vitamin E, mg/FU & 30.7 & 28.6 \\
(= $\alpha$-tocopherol equivalents) & & \\
\hline
\end{tabular}

${ }^{1}$ Provided per kg diet: 7.9 g Ca, 3.5 g P, 0.4 g Mg, 3.6 g $\mathrm{NaCl}, 105 \mathrm{mg} \mathrm{Fe}, 95 \mathrm{mg} \mathrm{Zn}, 46 \mathrm{mg} \mathrm{Mn}, 31 \mathrm{mg} \mathrm{Cu}, 1.2 \mathrm{mg}$ Co, $0.2 \mathrm{mg}$ I, $0.1 \mathrm{mg} \mathrm{Se}, 5000 \mathrm{IU}$ vitamin A, 800 IU vitamin $\mathrm{D}_{3}, 2 \mathrm{mg}$ thiamine, $7 \mathrm{mg}$ riboflavine, $4 \mathrm{mg}$ pyridoxine, $40 \mathrm{mg}$ nicotinic acid, $15 \mathrm{mg}$ pantothenic acid, $4 \mathrm{mg}$ folic acid, $140 \mu \mathrm{g}$ biotin, $20 \mu \mathrm{g}$ vitamin $\mathrm{B}_{12}$.

${ }^{2} \mathrm{FU}=$ feed unit. $1 \mathrm{FU}=9.3 \mathrm{MJ}$ net energy, calculated according to Tuori et al. (1995) based on published digestibility coefficients.

Pikul et al. (1989) incorporating the modifications of Yoshida et al. (1990) and Halliwell and Chirico (1993). In this analysis, thiobarbituric acid (TBA) reacts with fat oxidation products, such as malonaldehyde. A minced 10 -g meat sample, $1 \mathrm{ml}$ of $0.3 \%$ butylhydroxytoluene-ethanol solution $(\mathrm{w} / \mathrm{v})$ and $40 \mathrm{ml}$ of cold $\left(4^{\circ} \mathrm{C}\right) 10 \%$ trichloroacetic acid (TCA) solution (w/v) were mixed (Ultra turrax T25, Janke \& Kunkel) in a $50 \mathrm{ml}$ bottle for $2 \mathrm{~min}$ (13 $000 \mathrm{rpm})$. The suspension was rinsed from the mixer with $2 \mathrm{ml}$ of TCA-solution and from the bottle with $5 \mathrm{ml}$ of distilled water to a centrifuge tube and centrifuged (3000 rpm) for $5 \mathrm{~min}$. The supernatant was filtered through Whatman no 1 paper and diluted to $50 \mathrm{ml}$ with $10 \%$ TCA-solution. Then $5 \mathrm{ml}$ 
Suomi, K. et al. Effect of vitamin E on pigs and frozen pork

of this solution and $5 \mathrm{ml}$ of $0.02 \mathrm{M}$ TBA-solution were incubated in a $90^{\circ} \mathrm{C}$ water bath for 30 min. After being cooled down (10 min under running tap water) and filtered through $0.2 \mathrm{~mm}$ filter, absorbance was measured with a spectrophotometer at $532 \mathrm{~nm}$ against a blank containing 5 $\mathrm{ml}$ of $10 \%$ TBA-solution and $5 \mathrm{ml}$ of TBA-solution prepared in a similar manner to samples.

\section{Statistical analysis}

Experimental data was analysed using the MIXED procedure of SAS (Littell et al. 1996) and covariance parameters were estimated using residual maximum likelihood method. Performance and carcass data were analysed using the following mixed model (Snedecor \& Cohran 1989):

$\mathrm{Y}_{\mathrm{ijklm}}=\mu+\mathrm{B}_{\mathrm{i}}+\mathrm{B}_{\mathrm{j}}+\mathrm{E}_{\mathrm{k}}+(\mathrm{B} \times \mathrm{E})_{\mathrm{jk}}+\mathrm{S}_{1}+$ $(B \times S)_{j 1}+(E \times S)_{k l}+(B \times E \times S)_{i j k l}+e_{i j k l m}$,

where $\mathrm{B} 1$ is the random effect of block, and $B, E$ and $S$ are fixed effects of barley, level of vitamin E supplementation and sex, respectively. The model for the statistical analysis of serum $\alpha$-tocopherol content and enzyme activities, TBARS content and organoleptic quality of meat (mean score) was:

$$
\begin{aligned}
& \mathrm{Y}_{\mathrm{ijklm}}=\mu+\mathrm{B}_{\mathrm{i}}+\mathrm{E}_{\mathrm{j}}+(\mathrm{B} \times \mathrm{E})_{\mathrm{ij}}+\mathrm{e}_{\mathrm{ijk}}+\mathrm{T}_{1}+ \\
& (\mathrm{T} \times \mathrm{B})_{\mathrm{il}}+(\mathrm{T} \times \mathrm{E})_{\mathrm{jl}}+(\mathrm{T} \times \mathrm{B} \times \mathrm{E})_{\mathrm{ij} l}+\mathrm{e}_{\mathrm{ijklm}},
\end{aligned}
$$

where B, E and T are the fixed effects of barley, level of vitamin E supplementation and time, respectively. The effect of the level of the vitamin E supplementation was tested with orthogonal polynomials (linear, quadratic and cubic effect).

\section{Results}

Both stored and freshly harvested barley had a similar vitamin E content at the beginning of study (33.5 and $31.2 \mathrm{mg} / \mathrm{kg}$, respectively, Table
2). Vitamin E content of stored barley changed only little $(0.5 \mathrm{mg} / \mathrm{kg})$ during the course of the study (nearly four months) whereas that of freshly harvested barley increased by $7.5 \mathrm{mg} / \mathrm{kg}$. The $\alpha$-tocopherol content of barley changed in the same manner as the total vitamin $\mathrm{E}$ content. Basal stored and freshly harvested barley diets contained 27.7 and $25.9 \mathrm{mg} / \mathrm{kg}$ of vitamin $\mathrm{E}$ in the beginning, and 27.3 and $31.7 \mathrm{mg} / \mathrm{kg}$ at the end of the study, respectively. Both basal diets contained $0.3 \mathrm{mg} / \mathrm{kg}$ of selenium.

Most pigs ate their diet willingly and were healthy. Two pigs fed stored barley diet without supplemental vitamin E, and one pig fed stored barley diet with $160 \mathrm{mg} / \mathrm{kg}$ of vitamin $\mathrm{E}$ had a lower feed intake during the middle and end of the study, respectively. One pig fed stored barley diet was found at slaughter to have pleurisy. Incremental dietary vitamin $\mathrm{E}$ level had a curvilinear effect on weight gain $(\mathrm{P}<0.05)$ and tended to influence feed conversion ratio $(\mathrm{P}=0.06$, Table 3). The best performance was observed with $40 \mathrm{mg} / \mathrm{kg}$ of supplemental vitamin $\mathrm{E}$. The storage of barley did not affect pig performance (P > 0.05). Pigs ate slightly more dry matter for stored barley diets than those based on freshly harvested barley due to a higher dry matter content of the former. There were no differences in energy intake. Carcass quality did not differ between treatments. Dietary vitamin E supplementation had a cubic effect on back fat thickness ( $P$ $<0.05)$. Gilts grew faster and had less back fat and more lean in the carcass than barrows ( $\mathrm{P}<$ $0.05)$.

Before this trial, pigs had received a diet which contained only $25 \mathrm{mg} / \mathrm{kg}$ of supplemental vitamin $\mathrm{E}$, reflected by low serum $\alpha$-tocopherol content $(1.1-1.6 \mathrm{mg} / \mathrm{l})$ at the beginning of the study. Supplemental vitamin E increased linearly $(\mathrm{P}<0.001)$ serum $\alpha$-tocopherol concentration in samples taken $30 \mathrm{~d}$ after the beginning of the study and at slaughter (Fig. 1). The back fat $\alpha$ tocopherol content increased linearly $(\mathrm{P}<0.001)$ with incremental increases in dietary vitamin $\mathrm{E}$ supplementation. Although there were no differences between stored and freshly harvested barley diets in serum $\alpha$-tocopherol concentration, 
Vol. 8 (1999): 9-18.

Table 2. Content of vitamin E isomers and selenium in stored and freshly harvested barley at the beginning and the end of the experiment.

\begin{tabular}{|c|c|c|c|c|}
\hline & $\begin{array}{l}\text { Stored barley } \\
\text { beginning }\end{array}$ & end & $\begin{array}{l}\text { Freshly hat } \\
\text { beginning }{ }^{1}\end{array}$ & $\begin{array}{l}\text { ed barley } \\
\text { end }\end{array}$ \\
\hline$\alpha$-tocopherol, mg/kg & 17 & 15 & 15 & 18 \\
\hline$\alpha$-tocotrienol, $\mathrm{mg} / \mathrm{kg}$ & 52 & 57 & 51 & 66 \\
\hline$\beta$-tocopherol, $\mathrm{mg} / \mathrm{kg}$ & 1 & 1 & 1 & 1 \\
\hline$\gamma$-tocopherol, $\mathrm{mg} / \mathrm{kg}$ & 4 & 4 & 4 & 4 \\
\hline$\gamma$-tocotrienol, $\mathrm{mg} / \mathrm{kg}$ & 6 & 5 & 5 & 7 \\
\hline$\delta$-tocopherol, $\mathrm{mg} / \mathrm{kg}$ & 5 & 5 & 4 & 7 \\
\hline $\begin{array}{l}\text { Total vitamin } \mathrm{E}, \mathrm{mg} / \mathrm{kg} \\
(=\alpha \text {-tocopherol equivalent) }\end{array}$ & 33.5 & 33.0 & 31.2 & 38.7 \\
\hline Selenium, $\mathrm{mg} / \mathrm{kg}$ & 0.09 & & 0.10 & \\
\hline Dry matter, g/kg & 858.3 & & 865.1 & \\
\hline
\end{tabular}

${ }^{1} 6$ weeks post-harvest.

Table 3. Performance and carcass quality of pigs receiving different vitamin E supplements and diets based on stored (SB) or freshly harvested barley (FHB).

\begin{tabular}{|c|c|c|c|c|c|c|c|c|c|c|c|c|}
\hline & \multicolumn{4}{|c|}{ Vitamin E-suppl., mg/kg } & \multirow[b]{2}{*}{ SEM } & \multicolumn{3}{|c|}{ Signif. of vitamin $E^{1}$} & \multicolumn{2}{|l|}{ Barley } & \multirow[b]{2}{*}{ SEM } & \multirow[b]{2}{*}{ Signif. ${ }^{1}$} \\
\hline & 0 & 40 & $80^{2}$ & $160^{3}$ & & Lin. & Quadr & Cubic & SB & $\mathrm{FHB}^{4}$ & & \\
\hline $\mathrm{N}$ & 20 & 20 & 20 & 20 & & & & & 40 & 40 & & \\
\hline Final weight, $\mathrm{kg}$ & 110.4 & 113.5 & 112.0 & 109.7 & 1.15 & NS & * & NS & 111.3 & 111.5 & 0.81 & NS \\
\hline Weight gain, g/d & 803 & 833 & 823 & 805 & 10.0 & NS & $*$ & NS & 819 & 813 & 7.1 & NS \\
\hline $\begin{array}{l}\text { Feed consumption, } \\
\mathrm{kg} \mathrm{DM} / \mathrm{pig}\end{array}$ & 206 & 207 & 207 & 207 & 0.6 & NS & NS & NS & 206 & 207 & 0.4 & $*$ \\
\hline FU/pig & 215 & 216 & 215 & 216 & 0.6 & NS & NS & NS & 215 & 216 & 0.5 & NS \\
\hline $\begin{array}{l}\text { Feed conversion ratio, } \\
\text { FU/kg }\end{array}$ & 2.58 & 2.50 & 2.53 & 2.58 & 0.031 & NS & NS & NS & 2.54 & 2.56 & 0.022 & NS \\
\hline Number of pigs & 10 & 10 & 11 & 11 & & & & & 22 & 20 & & \\
\hline Carcass weight, $\mathrm{kg}$ & 83.7 & 85.4 & 85.0 & 81.8 & 1.39 & NS & NS & NS & 83.7 & 84.2 & 0.94 & NS \\
\hline Back fat thickness, mm & 25 & 26 & 23 & 28 & 1.3 & NS & NS & NS & 27 & 24 & 0.9 & NS \\
\hline $\begin{array}{l}\text { Side fat thickness, mm } \\
\text { Firmness of fat }\end{array}$ & 16 & 19 & 16 & 18 & 1.1 & NS & NS & * & 18 & 16 & 0.8 & NS \\
\hline (score 9-15) & 13.5 & 14.0 & 12.7 & 14.2 & 0.36 & NS & $*$ & $* *$ & 13.6 & 13.6 & 0.27 & NS \\
\hline $\begin{array}{l}\text { Lean in carcass, } \% \\
\text { Colour of meat }\end{array}$ & 57.1 & 56.5 & 57.7 & 56.5 & 0.55 & NS & NS & NS & 57.0 & 56.9 & 0.37 & NS \\
\hline Minolta (Light) & 52.9 & 54.8 & 53.7 & 52.1 & 1.53 & NS & NS & NS & 52.9 & 53.9 & 1.24 & NS \\
\hline
\end{tabular}

$\mathrm{DM}=$ dry matter, $\mathrm{FU}=$ feed unit.

${ }^{1}$ Significance: NS $=$ non-significant, $*(\mathrm{P}<0.05), * *(\mathrm{P}<0.01)$.

${ }^{2} \mathrm{SEM}$ value for carcass traits is 0.962 times the value given in the table.

${ }^{3}$ SEM value for carcass traits is 0.954 times the value given in the table.

${ }^{4} \mathrm{SEM}$ value for carcass traits is 1.045 times the value given in the table. 
Suomi, K. et al. Effect of vitamin E on pigs and frozen pork

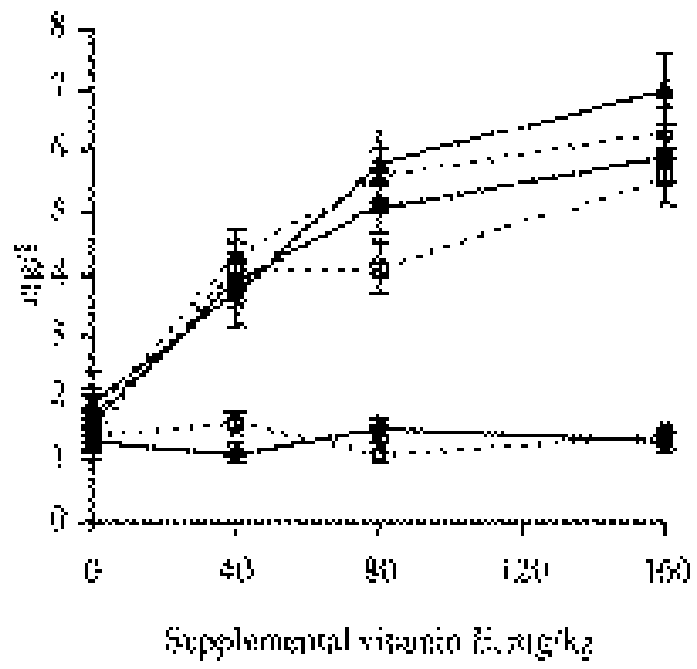

Fig. 1. Effect of supplemental vitamin E on the development of serum $\alpha$-tocopherol concentration (circle Day 0 , square Day 30 and triangle at slaughter) in growing-finishing pigs fed stored (- - ) or freshly harvested (------) barley $(\mathrm{N}=5$ pigs per treatment; Significance: vitamin effect $\mathrm{P}<0.001$, time effect $\mathrm{P}<0.001$, time $\times$ vitamin interaction $\mathrm{P}<0.001)$.

pigs fed FHB-diets tended to have a higher back fat $\alpha$-tocopherol content ( $P=0.06$, Fig. 2$)$. Plasma GSH-Px activity increased as pigs grew older $(\mathrm{P}<0.001)$. Dietary vitamin E supplementation decreased linearly $(\mathrm{P}<0.05)$ GSH-Px activity in plasma samples collected at slaughter (Fig. 3).

The TBARS content of pork stored frozen $\left(-18^{\circ} \mathrm{C}\right.$ for $\left.16 \mathrm{wk}\right)$ increased with time thawed meat samples were kept under fluorescent light $(\mathrm{P}<0.001)$ indicating a reduction in stability of fat against oxidation (Fig. 4). This was also noticed as a poorer taste whereas no effect was observed in meat tenderness or juiciness (Table 4). Dietary vitamin E supplementation did not affect the TBARS content or organoleptic quality of pork.

\section{Discussion}

The vitamin E content of stored barley decreased only a little during the experiment $(0.5 \mathrm{mg} / \mathrm{kg})$.

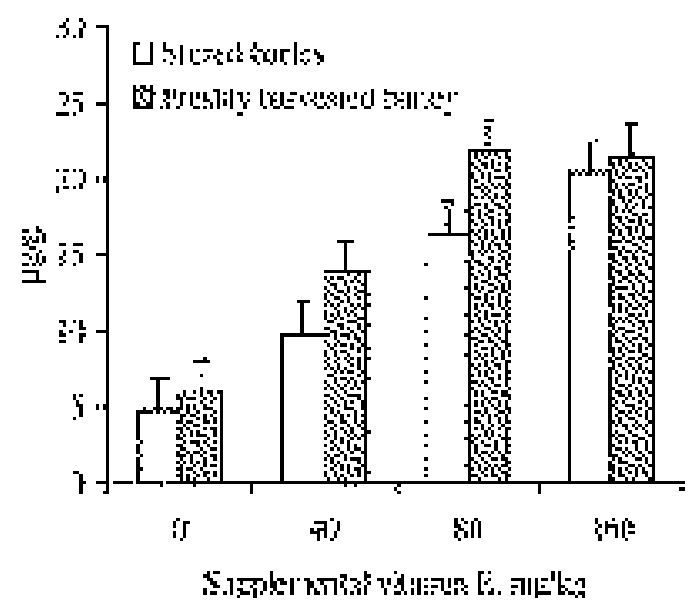

Fig. 2. Effect of barley storage and supplemental vitamin E on back fat $\alpha$-tocopherol concentration $(\mathrm{N}=5$ pigs per treatment; Significance of vitamin E level: linear $\mathrm{P}<0.001$, quadratic $\mathrm{P}<0.001)$.

According to Hakkarainen et al. (1983a) the vitamin E content of dried barley (13\% moisture content) decreased $10 \mathrm{mg} / \mathrm{kg}$ dry matter during 11 month storage which is somewhat higher than in this study. The vitamin E content of freshly harvested barley increased during the experiment

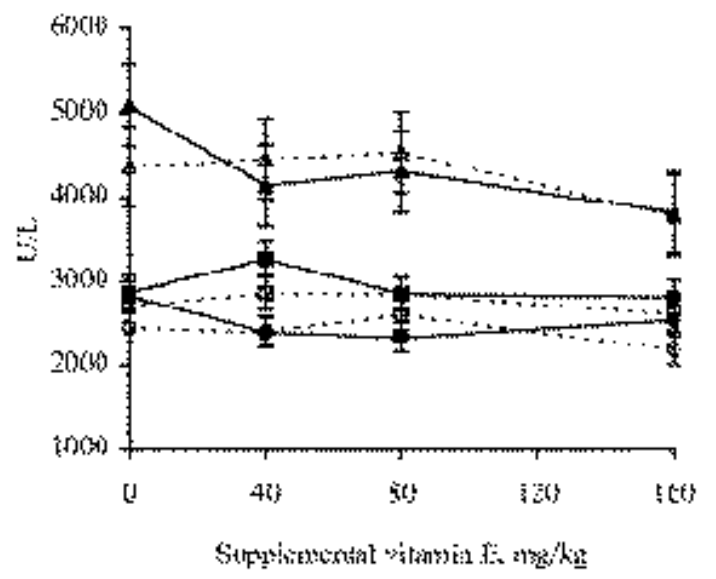

Fig. 3. Effect of supplemental vitamin E on the development of serum glutathione peroxidase activity (circle Day 0 , square Day 30 and triangle at slaughter) in growing-finishing pigs fed stored (- ${ }_{-}$) or freshly harvested (------) barley $(\mathrm{N}=5$ pigs per treatment; Significance: time effect $\mathrm{P}<0.001$, time $\times$ vitamin interaction $\mathrm{P}<0.05)$. 
Vol. 8 (1999): 9-18.

which started in October, one month after harvesting, and ended in January. This increase in natural vitamin $\mathrm{E}$ content of freshly harvested barley during storage is an interesting phenomenon and requires further study.

In this study, supplemental vitamin $\mathrm{E}$ had a quadratic effect on pig weight gain and optimal performance was observed with vitamin E supplementation of $40 \mathrm{mg} / \mathrm{kg}$ feed. In the study of Ashgar et al. (1991), vitamin E supplementation of 100 and $200 \mathrm{mg} / \mathrm{kg}$ improved pig growth and feed to gain ratio in the growing period compared with $10 \mathrm{mg} / \mathrm{kg}$ of vitamin E, but not in the finishing period. In our study, the effect of vitamin $E$ on pig performance was similar during both the growing and finishing periods. In general, vitamin $\mathrm{E}$ has had only minor effects on pig performance (Työppönen et al. 1988, Osborne et al. 1994). Storage of barley did not affect pig performance, and supplemental vitamin E above $40 \mathrm{mg} / \mathrm{kg}$ did not result in improved performance, when pigs were fed freshly harvested barley. This is in accordance with earlier results of Työppönen et al. (1988). Observed differences in the thickness and firmness of back fat between different barleys may be due to differences in dietary protein and lysine content. Higher protein and lysine content in freshly har-

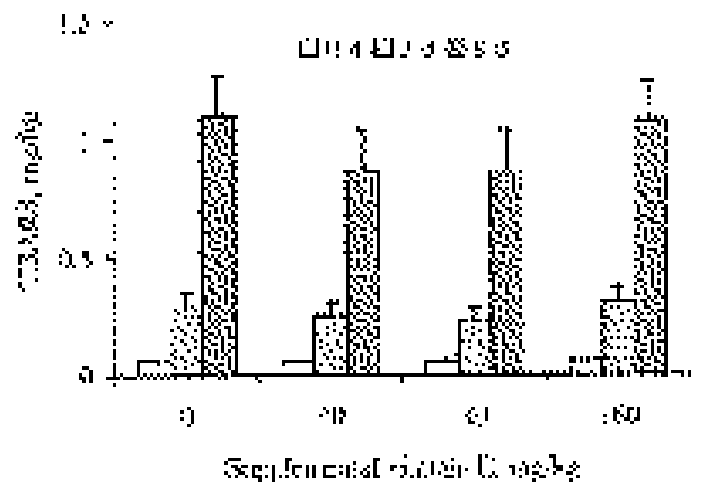

Fig. 4. Effect of supplemental vitamin E and time (0, 3 or 8 d) under fluorescent light on pork TBARS content $(\mathrm{N}=5$ pigs per vitamin $\mathrm{E}$ level; Significance: time effect $\mathrm{P}<0.001)$.

vested barley diet resulted in less back fat. Thicker back fat is generally firmer which was also observed in this study with barrows. In general, neither supplemental vitamin E nor the storage of barley has affected carcass composition (Osborne et al. 1994, Työppönen et al. 1988).

In the present study, dietary vitamin E supplementation increased serum $\alpha$-tocopherol concentration within a month after starting vitamin E supplementation. According to Jensen et al. (1990) dietary vitamin E supplementation in-

Table 4. Effect of supplemental dietary vitamin E on the organoleptic quality of frozen pork kept under fluorescent light at $4^{\circ} \mathrm{C}$ for 0,3 or 8 days.

\begin{tabular}{llllll}
\hline Vitamin E-suppl., mg/kg & 0 & 40 & 80 & 160 & SEM \\
\hline $\mathrm{N}$ & 5 & 5 & 5 & 5 & \\
$\quad$ Flavour ${ }^{1,2}$ & & & & & \\
$\quad$ Day 0 & 4.6 & 4.8 & 4.6 & 4.4 & 0.17 \\
$\quad$ Day 3 & 4.4 & 4.4 & 4.3 & 4.3 & 0.13 \\
$\quad$ Day 8 & 4.2 & 4.1 & 4.2 & 4.1 & 0.14 \\
$\quad$ Tenderness $^{1}$ & & & & & \\
$\quad$ Day 0 & 4.8 & 4.8 & 4.3 & 4.3 & 0.26 \\
$\quad$ Day 3 & 4.5 & 4.5 & 4.4 & 4.3 & 0.20 \\
$\quad$ Day 8 & 4.7 & 4.3 & 4.6 & 4.6 & 0.20 \\
Juiciness ${ }^{1}$ & & & & & \\
$\quad$ Day 0 & 4.5 & 4.8 & 4.6 & 4.5 & 0.11 \\
$\quad$ Day 3 & 4.4 & 4.6 & 4.3 & 4.6 & 0.12 \\
Day 8 & 4.7 & 4.4 & 4.3 & 4.4 & 0.12 \\
\hline
\end{tabular}

${ }^{1}$ Score 1 to 7 ( 1 is the lowest and 7 is the best score).

${ }^{2}$ Effect of time was significant at $\mathrm{P}<0.001$. 
Suomi, K. et al. Effect of vitamin E on pigs and frozen pork

creases serum $\alpha$-tocopherol concentration within a week. They suggested that serum $\alpha$-tocopherol concentration reflects short term changes in vitamin $\mathrm{E}$ intake, whereas tissue vitamin $\mathrm{E}$ concentrations (e.g. fat) reflect longterm changes in vitamin $E$ intake. In the current study, development of vitamin $\mathrm{E}$ in freshly harvested barley during the course of the experiment tended to increase back fat $\alpha$-tocopherol concentration. Serum $\alpha$-tocopherol concentration of pigs given no supplemental vitamin E remained low, less than $2 \mathrm{mg} / \mathrm{l}$, during the entire study. According to Jensen et al. (1988a), $3 \mathrm{mg} / \mathrm{l}$ of $\alpha$-tocopherol in serum is the minimun for normal functioning of immune cells. In their study, pigs that suffered from vitamin $\mathrm{E}$ and selenium deficiency had less than $1 \mathrm{mg} / \mathrm{l}$ of $\alpha$-tocopherol in serum. In the present study, pigs given no supplemental vitamin E had no clinical signs of vitamin E deficiency, such as muscular dystrophy. Both basal diets contained nearly $30 \mathrm{mg} / \mathrm{kg}$ of natural vitamin $\mathrm{E}$ that came from barley and soybean meal, in addition to added selenium. According to Ullrey (1981), $15 \mathrm{mg} / \mathrm{kg}$ of vitamin $\mathrm{E}$ and $0.135 \mathrm{mg} / \mathrm{kg}$ of selenium is enough to maintain normal tissue $\alpha$-tocopherol concentrations.

Plasma GSH-Px activity increased with pig maturity, which is in agreement with results of Jensen et al. (1988b). A linear response in plasma GSH-Px activity to the vitamin E supplementation level was observed only in blood samples collected at slaughter. Vitamin E supplementation has not been documented to have significant effect on GSH-Px activity. In this study, pigs were transported to the slaughter-house and the last blood samples were taken as the animals were bled. Transportation as a stressor may increase metabolic rate and hence the production of oxygen radicals. A decrease of cellular enzyme activity in plasma by vitamin E supplementation has been documented in stress-susceptible pigs (Duthie et al. 1989). Increases in the vitamin E level might protect cell membranes from damage during transportation, slaughter and preparation of the blood samples, subsequently reflected in plasma GSH-Px activity.
Dietary vitamin E supplementation did not improve the storage stability (measured as TBARS) of pork stored frozen for $16 \mathrm{wk}$. Higher vitamin E supplementation $(200 \mathrm{mg} / \mathrm{kg})$ has improved the storage stability of frozen pork (Monahan et al. 1992a, Pfalzgraf et al. 1995). In those studies, diets contained $3 \%$ of added fat (maize oil, soybean oil or tallow). Differences between studies are probably not related to vitamin E supplementation but to differences between added fats. Vegetable oils in particular, tend to increase the content of unsaturated fatty acids in tissues. Supplementary dietary vitamin $E$ has increased vitamin E content in cell membranes and stabilised muscle tissue which contains substantial amounts of unsaturated fatty acids (Monahan et al. 1992b). Finnish pig breeds have only minor quantities of intramuscular fat, circa 1.9\% (Kangasniemi and Honkavaara 1989), which may explain the lack of TBARS response to dietary vitamin E supplementation. According to Toulová et al. (1977) intramuscular fat contains more unsaturated fatty acids than depot fat and is thus more sensitive to oxidation.

In the present study, taste of pork was reduced the longer it was kept under fluorescent light as expected. Dietary vitamin E supplementation did not prevent off-flavours, nor did it increase meat tenderness or juiciness. However, numerical differences between treatments were seldom greater than one point, and the number of samples was perhaps too small to draw firm conclusions. According to Astrup (1973) vitamin E supplementation improves meat quality by decreasing off-flavours of meat, and off-flavours are related to oxidation of fat.

In conclusion, when growing-finishing pigs are fed freshly harvested or stored barley from good harvest conditions, $40 \mathrm{mg} / \mathrm{kg}$ of added vitamin $\mathrm{E}$ as all-rac- $\alpha$-tocopheryl acetate is sufficient to maintain serum $\alpha$-tocopherol concentration above $3 \mathrm{mg} / \mathrm{l}$, the level which is required for immune cell function. Increases in dietary vitamin E supplementation above $40 \mathrm{mg} / \mathrm{kg}$ did not improve pig performance, nor the storage stability or organoleptic quality of frozen pork. 
Vol. 8 (1999): 9-18.

\section{References}

AOAC 1990. Official methods of analysis. Association of Official Analytical Chemists, Inc., Arlington, Virginia. p. 69-90.

Asghar, A., Gray, J.I., Miller, E.R., Ku, P.-K., Booren, A.M. \& Buckley, D.J. 1991. Influence of supranutritional vitamin $\mathrm{E}$ supplementation in the feed on swine growth performance and deposition in different tissues. Journal of the Science of Food and Agriculture 57: 19-29.

Astrup, H.N. 1973. Vitamin E and the quality of pork. Acta Agriculturæ Scandinavica, Suppl. 19: 152-157.

Biesalski, H., Greiff, H., Brodda, K., Hafner, G. \& Bässler, K.H. 1986. Rapid determination of vitamin A (retinol) and $E$ ( $\alpha$-tocopherol) in human serum by isocratic adsorption HPLC. International Journal for Vitamin and Nutrition Research 56: 319-327.

Duthie, G.G., Arthur, J.R., Nicol, F. \& Walker, M. 1989. Increased indices of lipid peroxidation in stress-susceptible pigs and effects of vitamin E. Research in Veterinary Science 46: 226-230.

Günzler, W.A., Kremers, H. \& Flohe, L. 1974. An improved coupled test procedure for glutathione peroxidase (EC 1.11.1.9.) in blood. Zeitschrift fur Klinische Chemie und Klinische Biochemie 12: 444-448.

Hakkarainen, R.V.J., Työppönen, J.T. \& Bengtsson, S.G. 1983a. Relative and quantitative changes in total vitamin $\mathrm{E}$ and isomer content of barley during conventional and airtight storage with special reference to annual variations. Acta Agriculturæ Scandinavica 33: 395-400.

-, Työppönen, J.T. \& Bengtsson, S.G. 1983b. Changes in the content and composition of vitamin $E$ in damp barley stored in airtight bins. Journal of the Science of Food and Agriculture 34: 1029-1038.

Halliwell, B. \& Chirico, S. 1993. Lipid peroxidation: its mechanism, measurement, and significance. American Journal of Clinical Nutrition 57: 715S-725S

Jensen, M., Fossum, C., Ederoth, M. \& Hakkarainen, R.V.J. 1988a. The effect of vitamin $E$ on the cell-mediated immune response in pigs. Journal of Veterinary Medicine B 35: 549-555.

-, Hakkarainen, J., Lindholm, A. \& Jönsson, L. 1988b. Vitamin $E$ requirement of growing swine. Journal of Animal Science 66: 3101-3111.

-, Lindholm, A. \& Hakkarainen, J. 1990. The Vitamin E distribution in serum, liver, adipose and muscle tissues in the pig during depletion and repletion. Acta Veterinaria Scandinavica 31: 129-136.

Kangasniemi, R. \& Honkavaara, M. 1989. Intramuscular fat in the Finnish Landrace and Yorkshire breeds. In: 40 th Annual Meeting of the European Association for Animal production. Dublin, Ireland, 27-31 August. Summaries 1: 111-112.

Kivimäe, A. \& Carpena, C. 1973. The level of vitamin E content in some conventional feeding stuffs and the effects of genetic variety, harvesting, processing and storage. Acta Agriculturœ Scandinavica Suppl. 19: 161-168.

Kumpulainen, J. \& Saarela, K.-E. 1992. Determination of selenium in stable foods and total diets by electrothermal atomic absorption spectrometry without solvent extraction. Journal of Analytical Atomic Spectrometry 7: 165-170.

Littell, R.M., Milliken, G.A., Stroup, W.W. \& Wolfinger, R.D. 1996. SAS System for Mixed Models. SAS Institute Inc., Cary, NC. 633 p.

McLaughlin, P.J. \& Welhrauch, J.L. 1979. Vitamin E content of foods. Journal of the American Dietetic Association 75: 647-665.

Monahan, F.J., Asghar, A., Gray, J.I., Buckley, D.J. \& Morrissey, P.A. 1992a. Influence of dietary vitamin E ( $\alpha$-tocopherol) on the colour stability of pork chops. In: Proceedings of the 38th International Congress of Meat Science and Technology, Clermont-Ferrand, France, 23.-28.8.1992. Congress Secretariat of ICOMST, Helsinki. Volume 3, p. 443-546.

-, Buckley, D.J., Morrissey, P.A., Lynch, P.B. \& Gray, J.I. 1992b. Influence of dietary fat and $\alpha$-tocopherol supplementation on lipid oxidation in pork. Meat Science 31: 229-241.

Osborne, V.R., Evans, M., Hacker, R.R. \& Du, Z. 1994. The effect of dietary vitamin $E$ supplementation on pig growth, performance, pork colour and drip loss of fresh pork. Journal of Animal Science 72 (Supplement 1): 272.

Pearson, A.M., Love, J.D. \& Shorland, F.B. 1977. Warmed-over flavor in meat, poultry and fish. Advances in Food Research 23: 1-74.

Pfalzgraf, A., Frigg, M., Steinhart, H., Kirchgessner, M. \& Roth, F.X. 1995. Influence of dietary fat and vitamin $\mathrm{E}$ on the lipids in pork meat. Fat Science and Technology 97: 13-20.

Piironen, V., Varo, P., Syväoja, E.-L., Salminen, K. \& Koivistoinen, P. 1984. High-performance liquid chromatographic determination of tocopherols and tocotrienls and its application to diets and plasma of Finnish men. International Journal of Vitamin and Nutrition Research 53: 35-40.

Pikul, J., Leszczynski, D.E. \& Kummerow, F.A. 1989. Evaluation of three modified TBARS methods for measuring lipid oxidation in chicken meat. Journal of Agricultural and Food Chemistry 37: 1309-1313.

Pohjanheimo, O., Kurppa, M. \& Lohikoski, P. 1975. Ohran jyvien E-vitamiinipitoisuus tuleentumisen eri vaiheissa. Maatalouden tutkimuskeskus, Pohjois-Savon koeaseman tiedote n:o 1: 1-5.

Siljander-Rasi, H., Valaja, J., Alaviuhkola, T., Rantamäki, P. \& Tupasela, T. 1996. Replacing soya bean meal with heat-treated, low-glucosinolate rapeseed meal does not affect the performance of growing-finishing pigs. Animal Feed Science and Technology 60: 112.

Snedecor, G.W. \& Cochran, W.G. 1989. Statistical methods. $8^{\text {th }}$ ed., lowa University Press, Ames, lowa. 503 p.

Toulová, M., Ingr, I., Herzig, I. \& Najman, L. 1977. Effect on the stability of pork backfat and intramuscular fat of adding specific substances to commercial feed 
Suomi, K. et al. Effect of vitamin E on pigs and frozen pork

mixtures supplemented with non-edible fat from rendering plants. Acta Veterinaria, Brno 46: 47-56.

Tuori, M., Kaustell, K., Valaja, J., Aimonen, E., Saarisalo, E. \& Huhtanen, P. 1995. Rehutaulukot ja ruokintasuositukset. Yliopistopaino, Helsinki. 99 p.

Työppönen, J., Alaviuhkola, T. \& Suomi, K. 1988. Vitamin $E$ status and productivity of pigs fed with fresh or stored barley with or without vitamin E supplementation. Annales Agriculturæ Fenniæ 27: 153-162.

Ullrey, D.E. 1981. Vitamin E for swine. Journal of Animal Science 53: 1039-1056.

Yoshida, H., Hirooka, N. \& Kajimoto, G. 1990. Microwave energy effects on quality of some seed oils. Journal of Food Science 55: 1412-1416.

\title{
SELOSTUS
}

\section{Lihasikojen E-vitamiinin tarve ruokittaessa vastapuidulla ohralla ja rehuun lisätyn E-vitamiinin vaikutus lihan pakastussällyvyyteen ja syöntilaatuun}

\author{
Kaija Suomi, Kirsi Partanen, Timo Alaviuhkola, Hilkka Siljander-Rasi ja Satu Sankari \\ Maatalouden tutkimuskeskus ja Helsingin yliopisto
}

Kasvatuskokeessa selvitettiin E-vitamiinilisäyksen (all-rac- $\alpha$-tokoferyyliasetaattina) tarvetta ruokittaessa lihasikoja vastapuidulla, kuivatulla ohralla. Lisäksi selvitettiin, voidaanko tavanomaiseen rehuun lisätyllä runsaalla E-vitamiinimäärällä parantaa sianlihan pakastussäilyvyyttä ja syöntilaatua. Vastapuitu ja edelliskesänä puitu ohra olivat samaa Pohto-lajiketta, joita korjattaessa olosuhteet olivat hyvät. Koe aloitettiin kuukauden kuluttua ohran puinnista. Vastapuidun ohran E-vitamiinipitoisuus oli kokeen alussa 2,3 mg/ $\mathrm{kg}$ pienempi ja lopussa $5,7 \mathrm{mg} / \mathrm{kg}$ suurempi kuin varastoidun ohran. Koe oli $2 \times 4$ faktoriaalinen. Kummastakin ohrasta tehtyihin seoksiin lisättiin E-vitamiinia $0,40,80$ ja $160 \mathrm{mg} / \mathrm{kg}$. Yhteensä 80 sikaa, joiden alkupaino oli keskimäärin $26,6 \mathrm{~kg}$, jaettiin kahdeksaan ruokintaryhmään yksilöruokinnalle. Siat saivat rehua $1,2-2,8$ ry/pv 15 viikon ajan. Jokaisen ryhmän viidestä siasta otettiin verinäytteet ennen kokeen alkua, 30 päivän kuluttua kokeen alkamisesta ja teurastuksen yhteydessä E-vitamiinin ja glutationiperoksidaasientsyymin aktiivisuuden määritystä varten. Samojen sikojen ruhoista otettiin kyljysnäytteet silavan E-vitamiinimääritystä varten ja jokaisen E-vitamiinitason 5 eläimestä kyljysnäytteet lihan pakastusvarastoinnin kestävyysmääritystä varten. Viimeksi mainitut näytteet olivat pakastettuina vakuumipakkauksissa $\left(-18^{\circ} \mathrm{C}\right) 16$ viikon ajan. Sulatuksen jälkeen ne siirrettiin päivänvalolampun alle $\left(+8^{\circ} \mathrm{C}\right)$. Näytteistä määritettiin tiobarbituurihappoon reagoivat yhdisteet (TBARS) eli rasvan hapettumista kuvaava TBARS-luku päivänvaloon siirtopäivänä ja 3. ja 8 . päivänä siirron jälkeen.

Lisätty E-vitamiini paransi sikojen kasvua vain 40 $\mathrm{mg} / \mathrm{kg}$ lisäystasolla. Eri ohrilla ruokittujen sikojen kasvu oli samanlainen. E-vitamiinilisäys lisäsi veren seerumin $\alpha$-tokoferolipitoisuutta. Silavan $\alpha$-tokoferolipitoisuus suureni myös rehuun lisätyn E-vitamiinin myötä. Vastapuidulla ohralla ruokittaessa silavan $\alpha$-tokoferolipitoisuus oli hieman suurempi kuin varastoidulla ohralla ruokittaessa, johtuen ilmeisesti vastapuidun ohran E-vitamiinipitoisuuden kohoamisesta kokeen aikana. Sikojen plasman glutationiperoksidaasiaktiivisuus kohosi iän myötä, mutta väheni E-vitamiinipitoisuuden lisääntyessä rehussa teurastuksen yhteydessä otetussa näytteessä. Ilmeisesti lisääntynyt E-vitamiini yhdessä seleenin kanssa suojasi solukalvoja kuljetuksen ja teurastuksen aikana. Rehuun lisätyllä E-vitamiinilla ei ollut vaikutusta lihan pakastussäilyvyyteen, makuun, mureuteen eikä mehukkuuteen. Ruokittaessa sikoja vastapuidulla, hyvissä olosuhteissa korjatulla kuivatulla ohralla, riittää E-vitamiinilisäykseksi $40 \mathrm{mg} / \mathrm{ry}$. Suuremmat lisäykset eivät parantaneet lihan pakastusvarastointikestävyyttä eivätkä syöntilaatua. 